\title{
Other Macroeconomic Estimations
}

\begin{abstract}
White-collar crime is part of the shadow economy. The shadow economy may be any kind of illegal activity that causes damage to the financial interests of the country, performed by legal and illegal businesses. Just like the magnitude of white-collar crime cannot be specifically observed, the shadow economy is generally not observable, so its magnitude must be estimated. This can be done either by direct procedures at a microlevel, by indirect procedures that make use of macroeconomic indicators, or with statistical models to estimate the shadow economy. Given the uncertainty in all macroeconomic estimates of crime-be it whitecollar crime, tax evasion, or social security fraud-it is extremely important to be cautious in the application of such numbers in political and management arguments.
\end{abstract}

Keywords Gabriel Zucman • Hidden wealth $\bullet$ Labor market crime MIMIC approach $\bullet$ Money laundering • Offshore accounts $\bullet$ Panama Papers $\bullet$ Shadow economy $\bullet$ Tax evasion $\bullet$ Tax haven

White-collar crime is part of the shadow economy. The shadow economy is defined as the market-based production of goods and services, whether legal or illegal, that escapes detection in the official estimates of gross domestic product (GDP). The shadow economy comprises those economic

P. Gottschalk, L. Gunnesdal, White-Collar Crime in the Shadow Economy, https://doi.org/10.1007/978-3-319-75292-1_9 
activities and the income derived from them that circumvent or otherwise avoid government regulation, taxation, or observation (Schneider and Williams 2013).

The shadow economy is sometimes labeled the informal economy (Edelbacher et al. 2016: 1):

The informal economy is emerging worldwide as an antipode to the formal economy. Although only partially visible and parallel to the formal economic system, it is manifested in social and cultural activities in European cities in the tourist trade, in the form of vendors in the streets and squares or those selling flowers in restaurants. It has links to drug trafficking and prostitution, but also provides economic opportunities for immigrants, young people, and students. It has links with the formal economy, contributes to the forces of formal and informal social control, and is an important factor in the economies of European countries.

The shadow economy is illegal economic or non-complying economic activity within legal businesses existing alongside a country's official and legitimate economy, for example, transactions such as underdeclared income, undeclared work and overdeclared costs. The shadow economy is sometimes labeled the underground economy. It may be any kind of illegal activity that causes damage to the financial interests of the country, performed by legal and illegal businesses.

Here are some elements of the shadow economy:

- Organized use of fictitious invoices: Issuance and filing of invoices where the actual delivery of goods or services is not according to the statement. In the organized use of fictitious invoices, several people and companies are cooperating in a network in order to appear legitimate.

- Undeclared income: Keeping revenue, or parts of revenue, away from the official financial statements, and thus knowingly avoiding reporting. Operators keep the value added tax (VAT) paid by customers by not passing it on to the government, and in addition, they are saving income tax on the generated profits.

- Cross-border money transfers: Transferring, hiding, and illegally securing acquired proceeds. This is related to the second stage of the money laundering process, in which proceeds are converted or moved to create a distance from the crime source and crime scene. 
- Missing traders: Charging VAT when importing and selling goods, and subsequently disappearing without paying the tax to the government's collection authority. So-called "carousel fraud" is a method whereby goods are imported VAT free, but not sold for consumption in the relevant markets. Instead, the goods pass between several businesses, each of them liable to VAT, before being exported. The first link will often disappear without paying VAT, while the final link will reclaim VAT from the government.

- Misuse of companies: Establishing or changing the company as a concealment framework for illegal activities.

- Illegal workers: Using illegal workers often includes both illegal residence and illegal work, and can imply penalties for both the employer and the employee, if detected. A large demand for unreported employment and cheap labor seems to be an important driver.

- Use of legal business as shield: Hiding and laundering proceeds from the illegal economy.

- False identity for immigrants/refugees: Abusing identities includes false, stolen, or sold identity documents. Based on the application of incorrect information, false documents or documents belonging to another individual or a fake person, it may be possible to acquire a residence permit under false pretenses. False residence and work permits enable criminals to obtain employment, thereby causing the workplace to use illegal workers and pay wages under fraudulent social security numbers.

The main categories of white-collar crime include fraud, theft, manipulation, and corruption. When bank fraud is committed, bank costs increase, thereby reducing value creation in the bank. At the same time, the fraudster spends the illegal money. When theft is committed, organizational income decreases, thereby reducing value creation in the organization. At the same time, the thief consumes or uses the stolen goods and services. With manipulation, such as accounting manipulation, tax evasion may occur, which reduces government income. At the same time, the manipulator consumes or uses the withdrawn funds. With corruption, the values on the bribing side are reduced, while values on the bribed side are consumed or used.

The magnitude of white-collar crime cannot specifically be observed, and likewise the shadow economy is generally not observable, so its magnitude must be estimated (Breusch 2005). Schneider and Williams (2013) 
argue that there is no appropriate methodology to assess the scope of the shadow economy. Rather, there are three competing methods of assessment for the size of the shadow economy that are used:

1. Direct procedures at a micro level that aim to determine the size of the shadow economy at one particular point in time. An example is survey method.

2. Indirect procedures that make use of macroeconomic indicators in order to proxy the development of the shadow economy over time.

3. Statistical models that use statistical tools to estimate the shadow economy as an unobserved variable.

The most commonly used method of measurement is based on a combination of the multiple indicator multiple cause model (known as MIMIC) and the currency demand method. The MIMIC model assumes that the shadow economy remains an unobserved phenomenon which can be estimated using quantitatively measurable causes of shadow economic activity as well as indicators of illicit activity (Schneider and Williams 2013: 28):

The causes will include variables such as the tax burden and the intensity of regulation, and the indicators will include variables such as the demand for currency, official national income figure and official working hours data. The econometric models are complex and have to deal with a range of wellknown challenges such as endogeneity problems. For example, the size of the tax burden might make it more difficult for the government to raise taxes so it responds by raising tax rates and therefore the tax burden on the level of official national income.

The MIMIC model produces relative estimates of the size and development of the shadow economy. Typically, the shadow economy is estimated at around 14 percent in countries such as Norway. And 14 percent of GDP in Norway represents 420 billion NOK ( $\$ 53$ billion). In comparison, the shadow economy is estimated at 16 percent in Belgium, 14 percent in Sweden, 13 percent in Denmark and Germany, and 8 percent in Austria.

Petersen et al. (2010) suggest that the shadow economy can be identified as a single sector if a precise theoretical separation between sectors is made. If a clear concept of shadow activities is applied, the problem of tax evasion can also be identified in an appropriate way: tax evasion can take 
place in the market economy as well as in the shadow economy. The demarcation between criminal activities and shadow activities is of high relevance because the former does not positively contribute to total income or wealth while the latter can.

Evans (2016) suggests that viewed in a wider context of paid and unpaid informal economic activities, the shadow economy highlights four categories of economic activity:

1. Illegal economic activity: Generating goods and services that are forbidden by law and/or are unlawful when provided by unauthorized producers.

2. Paid informal economic activity: An activity that is hidden and thus not registered with or by the state, but the goods and services provided through it are otherwise deemed legal.

3. Self-provisioning: An activity that is undertaken by household members for themselves and/or for other household members.

4. Mutual aid: An activity carried out by household members for members of other households in the wider community.

Schneider et al. (2010) estimated the magnitude and development of the shadow economy all over the world, and the results for a few nations are listed in Table 9.1. The shadow economy in Norway exhibits a declining fraction of GDP from 19.2 percent in 1999 to 18.0 percent in 2007. Two comparable nations have similar results.

Schneider et al. (2010) suggest that the weighted average size of the shadow economy as a percentage of official GDP in Sub-Saharan Africa is 38.4 percent, in Europe and Central Asia it is 36.5 percent, and in highincome OECD countries (such as Norway) 13.5 percent.

The GDP in Norway is above 3 trillion NOK. In another application of MIMIC in 2017, the total magnitude of labor market crime was estimated.

Table 9.1 Shadow economy as a fraction (\%) of GDP (Schneider et al. 2010)

\begin{tabular}{lrrrrrrrrr}
\hline Country & 1999 & 2000 & 2001 & 2002 & 2003 & 2004 & 2005 & 2006 & 2007 \\
\hline Norway & 19.2 & 19.1 & 19.0 & 19.0 & 19.0 & 18.5 & 18.5 & 18.2 & 18.0 \\
Switzerland & 8.8 & 8.6 & 8.6 & 8.6 & 8.8 & 8.6 & 8.5 & 8.3 & 8.1 \\
Sweden & 19.6 & 19.2 & 19.1 & 19.0 & 18.7 & 18.5 & 18.6 & 18.2 & 17.9 \\
\hline
\end{tabular}


Labor market crime means all kinds of financial crime related to the supply of and demand for labor, such as social security fraud and tax evasion. Labor market crime is a violation of the law concerning wages and working conditions, social security, VAT, and tax evasion; organized crime contributes to the minimization of the production costs of goods and services and thus undermines social structures and distorts competition.

It was estimated in Norway by Samfunnsøkonomisk analyse (2017) that labor market crime represents more than 4 percent of GDP, thereby resulting in a total fraud of 95 billion $\mathrm{NOK}$ (\$12 billion). We return to this study below.

The Washington-based organization Global Financial Integrity (GFI) estimates that transnational crime is a $\$ 1.6$ trillion to $\$ 2.2$ trillion annual illegal business. However, there is no explicit methodology used to arrive at this enormous figure. Rather, it is the sum of many figures that are updated without any methodological explanations. In part, there are some observations that are multiplied by the likelihood of detection, such as the illegal arms trade.

\section{The MIMIC Model}

We have applied a bottom-up approach by expert elicitation for estimating the magnitude of white-collar crime. An alternative approach might be a top-down approach using econometric modeling where it is assumed that traces and evidence of white-collar crime can be found in the macroeconomy. One econometric modeling approach uses the MIMIC model, which is frequently applied to estimate the magnitude of the underground economy in society. It is an indirect approach using macroeconomic indicators as a proxy for the size of the underground economy (Imamoglu 2016). MIMIC has been exposed to serious criticism. For example, Breusch (2005) argues that the method is subjective and pliable in practice and thus unfit for the purpose of estimating unknown sizes such as the magnitude of the underground economy.

The MIMIC model might have been applied to our estimation of white-collar crime. One way would be to study the effect of additional control activities and see how much more crime was detected. This is an approach that has been applied in Norway not to estimate the magnitude of white-collar crime, but to estimate the magnitude of financial crime related to the labor market. We present the labor market study as follows. 
In step 1, a selection model is estimated that indicates the probability that an actor is selected for control related to labor market crime. In step 2 , a model is estimated that indicates the likelihood that the actor commits labor market crime, while at the same time correction for selection bias is introduced. In 2014, there were 976,372 business organizations in Norway that might be controlled; 3,025 business were selected for control and controlled. Among these businesses, 4.63 percent were caught committing labor marked crime.

Based on this fraction, Samfunnsøkonomisk analyse (2017) estimated that the total magnitude of labor market crime in Norway is 95 billion $\operatorname{NOK}(\$ 12$ billion).

MIMIC models are being used to estimate the size of the underground economy or the tax gap in various countries by applying structural equations. There are two kinds of observed variables in the model—causal variables and indicator variables-which are connected by a black box of unobservable factors. The challenge is first to estimate the contents of the black box.

The black box is typically estimated by a microanalysis. For example, microdata at the business level from the tax administration agency can be used to estimate the likelihood that an enterprise is conducting criminal offenses related to taxes and fees. The idea is that certain combinations of characteristics of businesses coincide with a higher probability of occupational crime than other characteristics.

An obvious weakness of these data is that they are not representative of populations, as controls are not conducted in a random selection. However, it is possible to use an estimation method developed to control the selectivity of the sample and thus find a likelihood of crime for all businesses.

The probability that an actor will get caught for tax evasion can be used to predict the extent of work-life crime, given different characteristics, such as industry or geographical area. Information from the internal revenue service as the tax authority (e.g., the Norwegian Tax Administration) can provide insights into characteristics of businesses that commit tax fraud and be used to estimate the extent of this kind of crime.

The process can be that the tax administration's overview of controlled businesses allows a mapping of the characteristics of the businesses that were taken for labor-related transactions in tax evasion. This information is then used to estimate the true visibility of a given activity in the population of all Norwegian companies involved in tax and tax crime. Furthermore, based on observed crime rates for those actually checked 
and on predicted crime rates for those not checked, it is possible to calculate average rates for the entire population.

A main problem with such a data set is that controls that are carried out are not random. The selection of control objects is risk-based, and controlled businesses are therefore not a representative sample of the population. To say something about the likelihood that those undetected by control actually perform illegal activities similar to those detected by control weakens the quality of the basis. Thus, a relevant variable is the nondetected businesses after control.

Factors that may affect the likelihood of labor-related deviant actions largely coincide with factors that influence control selection, as one wishes to control non-compliant actors. This contributes to skewness in the results. Such a skewed selection may provide incorrect an estimation and conclusion as to what may be relevant areas of action. This also allows for adjustments by business actors, because it can give an impression of what characteristics typically lead to control, thus allowing deviant actors to avoid standing out just on these criteria.

When the likelihood of control depends on factors that the offender may influence, such as recorded income, then the offender can influence the likelihood of detection. By providing a reported income that does not deviate too much from others in its industry, a business may have a low probability of being caught for tax evasion.

Randomized controls provide more valid results. A randomized control was conducted in Denmark, where the study concludes that the rate of tax avoidance is low. A key question in the study is: Are rules being followed because there is no possibility of evasion or whether there is a desire to act lawfully? The study found that a very small proportion $(0.3$ percent $)$ of those who were not responsible for reporting their own income to the authorities were cheating, while a large proportion (37 percent) of those who had their own responsibility to report income were cheating. Overall, the study concludes that the monetary amount lost to tax cheating is small.

Breusch (2005: 22) studied three applications of MIMIC and asked whether MIMC models are appropriate:

The MIMIC model has its origins in the factor analysis of psychometrics, where the correlations of observable variables are explained by common factors or unobservable latent variables. Whether or not a statistical model is suited to a particular application is to some extent a question of judgment, but there are extensions of the original psychometric factor model where the MIMIC structure seems natural. 
Breusch (2005: 23) argues that two MIMIC implications-alternative measurements of the same thing and lack of correlation between causes and latent variable - are problematic:

Both of these implications are unacceptable in the applications being considered here (the shadow economy). The first suggests that observed GDP and currency holdings are related to the various causal factors in the model - tax rates, unemployment rates, government expenditures, etc. - only through the size of the underground economy. Such a proposition is inconsistent with every known macroeconomic theory of income determination. The second proposition is equally implausible because it says that currency holdings are unrelated to observed income, once account is taken of the underground economy. If nothing else, that arrangement contradicts the currency demand model used in each of these studies to derive a benchmark value for calibrating the index from the MIMIC model.

Macroeconomic estimations are based on causality among variables. For example, many researchers assume that there is a causal relationship between unemployment rates and economic crime rates (e.g., Altindag 2012). They assume that higher unemployment rates cause higher economic crime rates. But it is not at all certain that this causality exists. Several researchers have questioned the use of unemployment rates as explanatory factors in econometric studies which address the relationship between the economy and crime (Yearwood and Koinis 2011).

For example, Yearwood and Koinis (2011) studied and tested the efficacy of the unemployment rate for predicting the reported property crime rate and to identify other economic indicators which may also prove to be useful for predicting crime rates with financial motives. Specifically, they looked at theft, burglary, robbery, fraud, and embezzlement. Given the exploratory nature of their research, seven stepwise regressions were computed with unemployment emerging as a significant predictor for only one of the criminal offenses. Research findings from their study identified alternative causal variables, such as average wage and salary disbursements, supplemental security income receipts, the consumer price index, and per capita personal income.

Yearwood and Koinis (2011) illustrate with their research how important it is to critically examine the use of unemployment rates and other variables in macroeconomic estimations of financial crime. While it certainly seems intuitively and theoretically plausible to assume that more unemployment causes more economic crime-simply because unemployed 
people must find economic means to serve their material needs-it is important to have a sound empirical as well as theoretical basis before causality is introduced in macroeconomic estimations.

In empirical terms, the unemployment rate proved to be neither a sufficient nor a statistically significant measure in six of Yearwood and Koinis' (2011) seven regression models. While Cebula (2012) argues that Yearwood and Koinis' (2011) models suffer from misspecification problems, it is nevertheless worth emphasizing that jumping on intuitively attractive causal relationships for variables that are easily available in public national statistics is simply not very smart in econometrics.

\section{Magnitude of Money Laundering}

Hendriyetty and Grewal (2017) studied the magnitude of money laundering in the world. Money laundering occurs when criminals try to conceal their proceeds of crime by deleting their tracks in financial systems, international trade, or through other efforts. Actions to conceal these proceeds, or funds derived from criminal acts, are intended to conceal the origin of the property so that it can appear legitimate. Money laundering is a global concern as it has significantly negative effects on the economies of both developed and developing countries.

The most widely quoted figure for the extent of money laundering is the International Monetary Fund's (IMF's) estimate of 2-5 percent of world GDP. An estimate for Austria is 1.2-1.8 percent, while another estimate is 6.5 percent in Europe. Hendriyetty and Grewal (2017) argue that measuring the extent of money laundering is extremely complex, and it is therefore necessary to calculate from a range of viewpoints according to the approaches used by criminals. They argue that the safest way for money launderers to conceal their proceeds of crime is to send the money out of the jurisdiction, so capital flows between countries associated with money laundering can be mistakenly defined as capital flight.

Therefore, Hendriyetty and Grewal (2017) suggest estimating the magnitude of money laundering based on capital flight. They list five approaches: the hot money method, the residual approach, the Dooley method, trade misinvoicing and illicit financial flows. The first approachthe hot money method-measures capital flight used as a short-term capital export by financial institutions. Capital flight is calculated by measuring private capital flows, taking the errors and omissions and private 
short-term capital accounts from the balance of payments. This type of capital flight is defined as "hot money" because it arises as a quick response to economic conditions.

As pointed out by Hendriyetty and Grewal (2017), there are major differences between money laundering and capital flight, especially in policy and monitoring processes. Money laundering occurs because criminals send their money abroad to avoid detection by law enforcement agencies. Capital flight occurs to avoid the jurisdiction applied to capital or foreign exchange control.

The second approach is the residual approach, where capital flight is measured as the sum of gross capital inflows and the current account deficit, less increases in official foreign reserves. Capital flight is estimated by measuring the difference between inflows and outflows. The third approach is the Dooley method which proposes capital flight as an offset of the stock claims held by non-residents that do not generate investment income. The fourth approach is trade misinvoicing involving the measurement of deviance in export and import invoicing. The fifth approach looks at illicit money flows from developing countries.

Hendriyetty and Grewal (2017) suggest economic approaches as an alternative to capital flight to estimate the magnitude of money laundering. Micro- and macroeconomic approaches include tax evasion as a basis for estimating money laundering.

\section{Magnitude of Tax Evasion}

Ceccato and Benson (2016) studied the effects of changes in tax policy in Sweden as a case study of tax evasion. They use the term "tax gap", which refers to the difference between the taxes that were actually paid to the government in a particular reporting period and what should have been paid according to the rules determined by tax agency controls. The tax gap in Sweden is assumed to be 9 percent.

Ceccato and Benson (2016: 218) apply situational crime prevention theory to study tax evasion:

Like rational choice theory and routine activity theory, situational crime prevention theory is part of what has been called the "opportunity" perspective on crime. The opportunity perspective first appeared on the criminological landscape four decades ago. In a nutshell, the opportunity perspective holds that opportunity is a fundamental cause of crime. The perspective assumes that individuals make choices to engage or not engage in crime 
based on the availability and attractiveness of criminal opportunities. Situational crime prevention theory seeks to identify the factors that influence the distribution and attractiveness of criminal opportunities and then to suggest ways in which attractiveness might be reduced. The theory predicts that reducing the attractiveness of criminal opportunities will lead to reductions in crime.

Based on situational crime prevention theory, Ceccato and Benson (2016) study how changes in tax policy in Sweden affect individuals' and companies' motivations for tax evasion. In 2015, changes in the Swedish tax policy effectively raised certain taxes and reduced tax discounts, and thereby made tax evasion more attractive to potential tax evaders. For example, one allowable deduction for so-called "rot services" (household/renovation services) was reduced from 50 percent to 30 percent of labor costs, with a maximum discount of 50,000 SEK per annum. A more generous tax deduction would mean that a series of situational conditions favorable to tax avoidance would diminish. When changes in tax policy reduce rewards associated with evasion, then the reward versus risk equation is altered for the potential tax evader.

Ceccato and Benson (2016: 229) make specific predictions regarding future trends in tax evasion.

Specifically, we predict that (1) if the Swedish Tax Agency does nothing except enforce the Rut/Rot tax as it has in the past and (2) if it continues to conduct the same surveys that it did between 2002 and 2013, then (3) a decrease in the indicators of tax compliance will be observed. The decrease will be more pronounced in some industries than in others, in particular construction, transportation, and hotels/restaurants.

Ceccato and Benson (2016) confirm that it is difficult to say how quickly tax compliance will fall and how great the decrease will be.

\section{Shadow Economy and Market Activities}

Petersen et al. (2010) present no estimate of the shadow economy. Rather, they try to shed some light on the definition of the shadow economy, in order to separate shadow activities from market activities and household production. They argue that the currency approach is not a promising concept for the estimation of the size of the shadow economy, since the factual influence of criminal activities on the money demand is unknown.

Petersen et al. (2010: 429) suggest that tax evasion and transfer fraud go hand-in-hand: 
Shadow income and transfers then often constitute a net real income (from transfers, shadow activities and household production) that is considerably higher than the respective person would be able to earn in the official labor markets: the reservation wage mentioned in the introduction then functions as a poverty trap, detaining people from a return into the market economy. Tax evasion and transfer fraud go hand-in-hand, making poverty an ever-persisting phenomenon, which also creates some jobs in the 'welfare industries', where the engaged people are always complaining about a permanently rising gap in between 'the poor' and 'the rich' and increasing poverty - thus, guaranteeing them even more work for the coming generations.

Petersen et al. (2010) suggest that tax evasion can be defined and identified in the market sector, and it is usually taking place in the shadow economy, where it is often accompanied by evasion of social security contributions as well as transfer fraud.

\section{Magnitude of Hidden Wealth}

Andersen et al. (2017: 2) estimate that 15 percent of the windfall gains accruing to petroleum-producing countries with autocratic rulers are diverted to secret accounts:

Political elites can abuse public office, or connections to those in the office, for private gain, and the struggle for state resources can have severe consequences in terms of political and economic instability.

Their dataset included country-level information about foreign-owned deposits in all significant financial centers including a number of important havens: jurisdictions that specialize in secrecy and asset protection such as Switzerland, Luxembourg, Cayman Islands, and Singapore. Their dataset constitutes a source of information on hidden wealth.

Andersen et al.'s (2017: 3) finding is that petroleum windfalls translate into significant increases in hidden wealth, but only when institutional checks and balances are weak:

Specifically, we estimate that a doubling of the oil price causes a 22 percent increase in haven deposits owned by petroleum-rich autocracies, corresponding to almost 1.5 percent of GDP at the sample mean, whereas there is no such effect on haven deposits owned by petroleum-rich non-autocracies. 
Since a doubling of the oil price is associated with an estimated 10 percent increase in the GDP of petroleum-rich countries, the result suggests that around 15 percent of the windfall gains accruing to countries with autocratic rulers is diverted to offshore accounts.

To establish the link between hidden wealth and political elites more firmly, Andersen et al. (2017) studied how tax haven deposits evolve in periods of increased political uncertainty. They found that haven deposits owned by autocracies start increasing significantly a few quarters before elections, suggesting that political elites anticipate the political risk inherent in elections and respond by hiding wealth in havens.

The methodological challenge facing this research was theoretical explanations for correlation and regression analysis. For example, income was correlated with hidden savings, while the regression was concerned with sham structures. As Andersen et al. (2017) point out themselves, it may be suspected that the correlation between petroleum rents and haven deposits is related to the presence of multinational firms in the petroleum industry. Through transfer pricing and thin capitalization, multinational firms shift taxable profits to havens, making developing countries vulnerable to tax avoidance. This may suggest an alternative explanation for the suggestion that oil and gas rents transferred to havens belong to multinational firms rather than domestic elites.

An editor in a Norwegian newspaper criticized estimates from Andersen et al. (2017) by refusing the claim that super-rich people pay little or no tax (Hegnar 2017: 2):

It has been speculated and researched how much is being avoided in taxation. Good numbers have not been received. There are mostly rough estimates of how much of GDP is assumed to be avoided and how much of the tax revenue it constitutes. A popular exercise in Norway has been using numbers from other countries (for example 5 percent or 10 percent of GDP) and apply this on Norwegian GDP, and thus there have been bombastic claims about tax evasion for several hundred billion kroner.

The hopelessness of these exercises is, for example, using numbers from a country like Italy, with a 25 percent unemployment rate, and comparing with Norway with an unemployment rate of 3-4 percent. It must be wrong. In a country where almost 70 percent are in work, and where the public sector is large and the benefits are high, it is less tax evasion than in Italy and similar countries. 
While we will return to the issue of abuse of macroeconomic estimates, it is interesting to note that both The Economist and the Guardian quote the same numbers. The Economist had the following headlines: "The super-rich are different: they pay less tax" and "The Swiss leaks and Panama papers open a window on the tax dodger's world". The Guardian had the following headlines: "Super-rich evade on average nearly third of their due tax" and "Chance of assets being hidden rises very sharply with wealth, finds economists' study based on Panama Papers data”.

\section{Wealth Held in Offshore Accounts}

Switzerland has, starting from the end of World War I, held a unique position amongst the world's centers of wealth management. Today, one-third of the world's offshore wealth is held there (Zucman 2015: 36). Other well-known tax havens such as the City of London, Hong Kong, Singapore, Jersey, Cayman Islands, Bahamas, and Luxembourg have emerged in the last couple of decades, following the same basic recipe as Switzerland (Zucman 2015: 23):

In all these tax havens, private bankers do the same things as in Geneva: they hold stock and bond portfolios for their foreign customers, collect dividends and interest, provide investment advice as well as other services, such as the possibility of having a current account that earns little or nothing. And, thanks to the limited forms of cooperation with foreign tax authorities, they all offer the same service that is in high demand: the possibility of not paying any taxes on dividends, interest, capital gains, wealth, or inheritances.

Zucman (2015) estimates that on a global scale households owned 8 percent of their financial wealth through bank accounts in tax havens in 2014 , amounting to $\$ 7.6$ trillion. For Europe alone, the estimated share is 10 percent, or $\$ 2.6$ trillion. This fraud translates into a conservative estimate for lost tax revenues for the world as a whole of $\$ 190$ billion annually. Zucman's estimate is considerably lower than a previous estimate made by James Henry from the Tax Justice Network (Henry 2012), claiming that between $\$ 21$ and $\$ 32$ trillion was invested through the world's still expanding "black hole" of more than 80 tax havens. Both estimates look at financial wealth, in other words the sum of all the bank deposits, portfolios of stocks and bonds, shares in mutual funds, and insurance contracts held by individuals throughout the world, net of any debt. 
They must be considered lower bounds for the actual wealth accumulated by the super-rich. Zucman (2015: 44-45) notes that his estimate does not include real estate in foreign countries, or non-financial wealth like works of art, jewelry and gold stashed anonymously in repositories in places like Geneva, Luxembourg and Singapore:

High net-worth individuals also own real estate in foreign countries: islands in the Seychelles, chalets in Gstaad, and so on. Registry data show that a large chunk of London's luxury real estate is held through shell companies, largely domiciled in the British Virgin Islands, a scheme that enables owners to remain anonymous and to exploit tax loopholes. Unfortunately, there is no way yet to estimate the value of such real assets held abroad.

Zucman's estimate of hidden financial wealth is made by examining anomalies in the balance sheets that record the assets and liabilities between countries. Zucman (2015: 37) gives the following example:

[L]et's imagine a British person who holds in her Swiss bank account a portfolio of American securities-for example, stock in Google. What information is recorded in each country's balance sheet? In the United States, a liability: American statisticians see that foreigners hold US equities. In Switzerland, nothing at all, and for a reason: the Swiss statisticians see some Google stock deposited in a Swiss bank, but they see that the stock belongs to a UK resident - and so they are neither assets nor liabilities for Switzerland. In the United Kingdom, nothing is registered, either, but wrongly this time: the Office for National Statistics should record an asset for the United Kingdom, but it can't, because it has no way of knowing that the British person has Google stock in her Geneva account.

As we can see, an anomaly arises-more liabilities than assets will tend to be recorded on a global level. And, in fact, for as far back as statistics go, there is a "hole": if we look at the world balance sheet, more financial securities are recorded as liabilities than as assets, as if planet Earth were in part held by Mars.

The secrecy surrounding tax havens like Switzerland, makes it difficult to ascertain who owns the hidden wealth, and thus which individuals are evading taxes, and by how much. Estimates of tax evasion have typically been based on random tax audits. But these audits include very few individuals at the very top of the wealth and income distribution, and they fail to detect evasion involving shell companies and hidden accounts. This also 
means that measures of wealth inequality that are based on tax data alone will grossly underestimate the actual amount of wealth at the top of the pyramid.

Research by Alstadsæter et al. (2017), analyzes data made available by two massive leaks from offshore financial institutions. The first data were obtained in 2007 from the internal records of HSBC Private Bank. Known as "Swiss Leaks", they were released in 2015 by the International Consortium of Investigative Journalists (ICIJ). One leak included the names of the owners of the wealth the bank managed, even when the ownership was concealed through a network of shell companies in offshore tax havens. The other leak, knows as "The Panama Papers", was released in 2016 by the ICIJ. It contained the names and addresses of the owners of shell companies created by the Panamanian firm Mossack Fonseca. It confirmed that the use of tax havens rises steeply with wealth. Thirdly, an additional source of information comes from households who have previously disclosed their hidden wealth voluntarily in exchange for reduced penalties due to tax amnesties in Norway and Sweden.

Combining information from these sources with administrative income and wealth records in Norway, Sweden, and Denmark, the researchers observe a sharp upward gradient in tax evasion by wealth groups. The average evasion of taxes as a percent of taxes owed is estimated around 3 percent. Households in the top 0.01 percent, however, a group of households each with more than $\$ 40$ million in net wealth, evades about 30 percent of its personal income and wealth taxes (Alstadsæter et al. 2017:2). The propensity to hide wealth also seems to rise sharply with wealth. The top 0.01 percent of Norwegian and Swedish households, each with more than $\$ 40$ million in net wealth, is found to be 250 times more likely than average to hide their assets. This group owns about 50 percent of all wealth held offshore, hiding about 25 percent of their true wealth from the authorities. The authors point out (Alstadsæter et al. 2017: 3-4):

Our results highlight the need to move beyond tax records to capture the income and wealth of the very rich, even in countries where tax compliance is generally high. They also suggest that tax data may significantly underestimate the rise of wealth concentration over the last four decades, as the world was less globalized in the 1970s, it was harder to move assets across borders, and offshore tax havens played a less important role. Because most 
Latin American, and many Asian and European economies own much more wealth offshore than Norway, the results found in Scandinavia are likely to be a lower bound for most of the world's countries.

It is important to remember that simply owning a bank account in places like Switzerland is not a crime per se: but not reporting it to the tax authorities is. The study shows that about 95 percent of the Norwegian and Danish individuals identified as owning an account in HSBC Switzerland, had not reported it, allowing the researchers to identify them as tax evaders.

Alstadsæter et al.'s (2017) work shows that among Scandinavians with bank accounts in Switzerland, 95 percent failed to provide information about these to the Inland Revenue Service. The study also shows that the hidden foreigners are strongly concentrated in the approximately 1100 richest families in Scandinavia, which make up about 0.01 percent of the population. The findings do not support the hypothesis that the most resourceful among us are the most honorable. Nor do they find support for the claim that many own a bank account in Switzerland for legitimate reasons. On the contrary, the findings indicate that most people who choose to put their money into a tax haven do it as financial criminals (Jacobsen and Coll 2017).

\section{Abuse of Macroeconomic Estimates}

Given the uncertainty in all macroeconomic estimates of crime-be it white-collar crime, tax evasion, or social security fraud-it is extremely important to be cautious in the application of such numbers in political and management arguments. While it may be easy for journalists, politicians, law enforcement, and others to grab a large number and use it for their own agenda and in their own context, abuse of numbers with an intentional purpose is very unethical. Therefore, we must caution every reader not to jump on a bandwagon that the magnitude of white-collar crime is 12 billion NOK in Norway and thus must be billions of dollars in the United States ( $\$ 96$ billion) by assuming the same occurrence rate in a much larger population.

An example can be drawn from the Norwegian daily business newspaper Dagens Neringsliv in which it was claimed that attorneys from global auditing firm PwC abused social security estimates from NAV, which we discussed earlier in this book, to emphasize that employers should not 
believe employees who claim they are sick. The newspaper's front page was covered with the following statement: "Ask employers to intervene against cheating with sickness reports", by PwC lawyers Ida Solberg Henning and Lene Sakariassen (Kaspersen 2017: 22-23):

Misuse of the sickness benefit scheme costs two to three billion a year. This is something employers can and should do something about, says PwC lawyers.

Between six and eight percent of the sickness payout is probably not enough justified or direct abuse of the sickness benefit scheme, according to a report Proba Research prepared on behalf of the Ministry of Labor. It indicates between 2.2 and 2.9 billion annual costs, based on what is granted for sickness benefit over the state budget for 2017.

"If the employer has clear indications that an employee is not ill, he has the opportunity to contest the sickness report, i.e. refusing to pay for the first 16 sick days", says lawyer Ida Solberg Henning, who works with labor law at the law firm PwC.

The employer generally has a duty to pay sickness benefits for the first 16 calendar days a worker is ill. After that, Nav assumes responsibility.

To be entitled to sickness benefit, you must be unemployed because of a disability that is clearly due to your own illness or injury. Henning and colleague Lene Sakariassen emphasize that most of the sickness reports are legitimate, but in some cases it is clear that the conditions for sickness benefits are not met.

"For example, if a worker becomes ill-reported when he or she has been refused leave for vacation, there is a conflict at work, or if the employee is at risk of termination", Henning says.

The lawyers emphasize that there is a risk associated with such a process. Should the disputes prove to be based on a wrong basis, this could have consequences for the company - both economically and for the internal working environment.

That's why there are many employers who are struggling to address problems with sickness and sick leave.

"But to contest sickness reports that are strongly suspected to be incorrect is to take on corporate social responsibility", claim the $\mathrm{PwC}$ attorneys.

A week's sick leave costs an average Norwegian employer around 15,000 kroner, which is a number from Sintef. In addition to the fact that the employer has to pay sickness benefits, costs related to production losses, any expenses for a replacement and overtime may occur.

"Employers' expenses related to the sick leave absence period which are not sufficiently justified or direct abuse of the sickness benefit scheme amount to several hundred million kroner a year. Costs related to sickness 
absence extending beyond the employer's period come in addition", summarizes Ida Solberg Henning.

In a report prepared by Oxford Research, it appears that the Appeals Committee for Social Security in the Employer's Period had 86 such cases about the employee's incapacity for work in the years 2014-2015. In two out of three cases, the employer won the case.

"Then it's natural to think that employers have helped to prevent abuse of the sickness benefit scheme," PwC lawyers point out.

Fortunately, some estimates are better founded than others. The research by Alstadsæter et al. (2017) is one such example (Jacobsen and Coll 2017: 28):

Most previous studies on individuals' tax evasion in tax havens have either had to make use of estimates, or highly aggregated data. Here, however, the researchers have used unique data sets from data leakages SwissLeaks and Panama Papers. This is information obtained directly from banks and law firms in tax havens, which they have been able to match with data from the Scandinavian tax authorities.

\section{REFERENCES}

Alstadsæter, A., Johannesen, N., \& Zucman, G. (2017). Tax Evasion and Inequality (Working Paper). Paper and Data Appendix available at: http://gabriel-zucman.eu

Altindag, D. T. (2012). Crime and Unemployment: Evidence from Europe. International Review of Law and Economics, 32, 145-157.

Andersen, J. J., Johannesen, N., Lassen, D. D., \& Paltseva, E. (2017). Petro Rents, Political Institutions, and Hidden Wealth: Evidence from Offshore Bank Accounts. Journal of the European Economic Association, Volume 15, Issue 4, 1 August 2017, Pages 818-860, https://doi.org/10.1093/jeea/jvw019

Breusch, T. (2005). Estimating the Underground Economy Using MIMIC Models. Paper provided by EconWPA in its series Econometrics with number 0507003. http://econwpa.repec.org/eps/em/papers/0507/0507003.pdf

Cebula, R. J. (2012). Revisiting Property Crime and Economic Conditions: An Exploratory Study to Identify Predictive Indicators Beyond Unemployment Rates - Comment. The Social Science Journal, 49, 314-316.

Ceccato, V., \& Benson, M. L. (2016). Tax Evasion in Sweden 2002-2013: Interpreting Changes in the Rot/Rut Deduction System and Predicting Future Trends. Crime, Law and Social Change, 66, 217-232. 
Edelbacher, M., Dobovsek, B., \& Kratcoski, P. C. (2016). The Relationship of the Informal Economy to Corruption, Fraud, and Organized Crime. In M. Edelbacher, P. C. Kratcoski, \& B. Dobovsek (Eds.), Corruption, Fraud, Organized Crime, and the Shadow Economy. Boca Raton: CRC Press, Taylor \& Francis.

Evans, M. (2016). Social Capital and the Shadow Economy. Journal of Economic Issues, $L(1), 43-58$.

Hegnar, T. (2017, June 9, Friday). De superrike og skatt [The Super-Rich and Tax]. Daily Norwegian financial newspaper Finansavisen, p. 2.

Hendriyetty, N., \& Grewal, B. S. (2017). Macroeconomics of Money Laundering: Effects and Measurements. Journal of Financial Crime, 24(1), 65-81.

Henry, J. (2012). The Price of Offshore Revisited. New Estimates for "Missing" Global Private Wealth, Income, Inequality, and Lost Taxes. Tax Justice Network.

Imamoglu, H. (2016). Re-estimation of the Size of Underground Economy in European Countries: MIMIC Approach. International Journal of Economic Perspectives, 10(1), 171-193.

Jacobsen, S. K., \& Coll, I. A. E. (2017, June 10, Saturday). Galskap å legge ned Økokrim [Madness to Close Down Økokrim (Norwegian National Authority for Investigation and Prosecution of Economic and Environmental Crime)]. Daily Norwegian Business Newspaper Dagens Naringsliv, p. 28.

Kaspersen, L. (2017). Ber sjefen gripe inn mot juks med sykemeldinger. Dagens Noringsliv, mandag 12. januar, side 22-23.

Petersen, H. G., Thiessen, U., \& Wohlleben, P. (2010). Shadow Economy, Tax Evasion, and Transfer Fraud - Definition, Measurement, and Data Problems. International Economic Journal, 24(4), 421-441.

Samfunnsøkonomisk analyse. (2017). Analyse av former, omfang og utvikling av arbeidsmarkedskriminalitet [Analysis of the Forms, Scope and Development of Labor Market Crime]. Oslo: Samfunnsøkonomisk analyse. www. samfunnsokonomisk-analyse.no

Schneider, F., \& Williams, C. C. (2013). The Shadow Economy. London: The Institute of Economic Affairs.

Schneider, F., Buehn, A., \& Montenegro, C. E. (2010). Shadow Economies All over the World: New Estimates for 162 Countries from 1999 to 2007. The World Bank, Development Research Group, Poverty and Inequality Team. www.gfintegrity.org. Yearwood, D. L., \& Koinis, G. (2011). Revisiting Property Crime and Economic Conditions: An Exploratory Study to Identify Predictive Indicators Beyond Unemployment Rates. The Social Science Journal, 48, 145-158.

Zucman, G. (2015). The Hidden Wealth of Nations. The Scourge of Tax Havens. The University of Chicago Press. http://gabriel-zucman.eu/hidden-wealth/ 
Open Access This chapter is licensed under the terms of the Creative Commons Attribution 4.0 International License (http://creativecommons.org/licenses/ by $/ 4.0 /$ ), which permits use, sharing, adaptation, distribution and reproduction in any medium or format, as long as you give appropriate credit to the original author(s) and the source, provide a link to the Creative Commons license and indicate if changes were made.

The images or other third party material in this chapter are included in the chapter's Creative Commons license, unless indicated otherwise in a credit line to the material. If material is not included in the chapter's Creative Commons license and your intended use is not permitted by statutory regulation or exceeds the permitted use, you will need to obtain permission directly from the copyright holder.

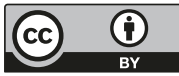

